\title{
Challenges for Quality Primary Education in Papua New Guinea-A Case Study
}

\author{
Ravinder Rena ${ }^{1,2}$ \\ ${ }^{1}$ Department of Business Studies, Papua New Guinea University of Technology, Lae, Papua New Guinea \\ ${ }^{2}$ African Master's Programme in Comparative Local Development, Harold Pupkewitz Graduate School of Business, Polytechnic of \\ Namibia, Private Bag 13388, Windhoek, Namibia
}

Correspondence should be addressed to Ravinder Rena, rravinder@polytechnic.edu.na

Received 23 August 2010; Revised 26 December 2010; Accepted 1 March 2011

Academic Editor: Kit Tai Hau

Copyright (C) 2011 Ravinder Rena. This is an open access article distributed under the Creative Commons Attribution License, which permits unrestricted use, distribution, and reproduction in any medium, provided the original work is properly cited.

\begin{abstract}
There is an urgent need to reform the educational system to achieve universal primary education in Papua New Guinea (PNG). Even after 35 years of independence, PNG has been struggling to educate an estimated 2 million elementary- and primary-aged children and faces numerous challenges in providing Education for All (EFA). This study was conducted in four primary schools of Buma Yong area of Lae district of Morobe Province, PNG. The study revealed that the quality of education has been deteriorated over the past few decades. Many schools in PNG do not have classrooms, teachers, and basic facilities. As a result, the children are losing interest in going to school. The children dropped out of school so as to assist their families in the household and agricultural activities. It also reveals that the dropout rate of girls is more than that of the boys due to the gender disparity in the country. The study recommended that budgetary allocations should be increased so as to improve the infrastructural facilities and encourage the children to attend primary school and thus achieve the Millennium Development Goal/Education For All in PNG.
\end{abstract}

\section{Introduction}

In April 2000, representatives of 164 countries, including PNG, met at Dakar, Senegal, to discuss and consider the issues to relate to education. At the conclusion of the conference, six goals were adopted by the international community which has come to be known as the education for all (EFA) goals. This paper mainly addresses the issues related with two goals of EFA: (1) ensuring that by 2015, all children, particularly girls, children in difficult circumstances and those belonging to ethnic minorities, have access to and complete free and compulsory primary education of good quality and (2) eliminating gender disparities in primary and secondary education by 2005 , and achieving gender equality in education by 2015, with a focus on ensuring girls' full and equal access to, and achievement in, basic education of good quality.

In the year 2000, the United Nations Millennium Declaration was adopted by 190 countries around the world. This declaration was a seminal occurrence and constituted an unprecedented promise by world leaders to address peace, security, development, human rights, and fundamental freedoms [1]. PNG was among the countries that adopted the Millennium Development Goals and thereby committed to meeting the eight goals by the year 2015 (Millennium Development Goals: (1) eradicate extreme poverty and hunger, (2) achieve universal primary education, (3) promote gender equality and empower women, (4) reduce child mortality, (5) improve maternal health, (6) combat HIV/AIDS, malaria and other diseases, (7) ensure environmental sustainability, and (8) develop a global partnership for development [1]).

Progress in education is critical for human development in its own right and because of the links to health, equity, and empowerment [2]. In line with this, Asian Development Bank (ADB) and other donors are fully supportive of Education For All and achieving the MDGs, especially countries like PNG which lags behind in universal basic education. Currently, the international community has been debating how best to provide the substantial resources to get children into school and then keep them interested to pursue studies through at least primary classes. Unfortunately, this is not easy for countries like PNG, where many students who 
do not attend schools (are located in rural areas), where schools and teachers are not readily accessible, and where opportunity costs limit attendance.

Universal primary education remains a national goal, but the PNG National Department of Education has encountered several challenges trying to achieve it. The primary school system suffered from a lack of teachers and funds [3]. Moreover, not all provinces support the national goal or see the need to provide basic education to all citizens. Consequently, many provinces have focused on expanding their secondary schools and but not their primary ones.

1.1. Relevant Literature. There has been a widespread belief that educational development would lead to an accelerated economic growth, more wealth and income distribution, greater equality of opportunity, availability of skilled human power, a decline in population growth, national unity, and political stability [4-6]. This belief has made many individuals and nations to invest immensely in education; of course, PNG is also driving in the same path.

Indeed, education becomes a big business all over the world. In his works on this subject, Schultz [7] has emphasized that population quality and knowledge constitute the principal determinants of the future welfare of mankind. Expounding on this further, Harbison [8] posits that the wealth of nations depends on the development of its human resources and not so much on its physical resources. He argues that "a country which is unable to develop the skills and knowledge of its people and to utilize them effectively in the national economy will be unable to develop anything else".

According to Psacharopolous [9], education is considered the route to economic prosperity, the key to scientific and technological advancement, the means to combat the unemployment, the foundation of social equality, and the spearhead of political socialization and cultural diversity. It is this recognition of the noble role of education in PNG society that has led for several years to the historic struggle over the control of education, that is, formal education in Papua New Guinea (PNG).

This struggle has led to numerous conflicting interests among various "actors" in education in both colonial and postcolonial PNG. But today's struggle in PNG education is no longer about seeking to regain control of the school, both privately and publicly; instead, it concerns the quality of education as provided in the school, in the family, and in the society. Today's educational struggle in PNG is a struggle for pedagogy, more specifically, PNG pedagogy that is responsive to the PNG condition today. It is a pedagogy according to Gore [10] that requires well-defined "instruction and vision" in educational theorizing. It is a pedagogy that is expected to be: liberating, empowering and responsive to societal needs. This requires offering of reflective education that attends mindfully to the social and political context of educating, as well as to its technical and practical aspects.

Role of $A D B$ in Educational Development. Loxley [11] concluded that the demographics probably will determine the final success of economic development in the Asia region. He however, opined that demographics definitely will determine the size and shape of the education systems in Asia as well as their structure and costs for years to come. Governments will have to decide who to educate, what kind of education to provide, and how to pay for it. He further highlighted that the challenge for Asia is to find low-cost solutions that offer quality basic education to half the world's population when its estimated public expenditures on education in 1997 amounted to 7 per cent of the world's spending on education.

In 2003, ADB reported that new methods of financing basic education need to be found if countries like Pakistan and Bangladesh, as well as parts of India, are to successfully provide sustainable, low-cost, quality basic education to their children. The sustainability issue is especially important because, until South Asian countries sufficiently develop economically to absorb the cost of public education (as a public good), it is not likely that tens of millions of students can be accommodated adequately-especially when South Asia has 23 per cent of the world's student population but spends only 2 per cent of the world's total public expenditure on education. Financing education in South Asia is a real dilemma for which no simple answers presently exist [12].

School finance poses challenges for education systems found among member countries of the Asian Development Bank (ADB) and of the Commonwealth. Consequently, Asian countries will have to decide the best way to maximize educational services at least cost if development is to occur. $\mathrm{ADB}$ forecast that neither economic nor social change is likely to occur without a literate and healthy population, education is a major determinant of development everywhere in Asia and the Pacific. Further ADB concluded that Pakistan is a nation of 140 million with a gross enrolment rate of about 80 per cent but high dropout in elementary schools. Given the historical ties to modest public education spending, it has been difficult for the provinces to provide universal education, especially in rural areas. ADB has emphasised basic education as a means to get more students enrolled, especially girls. ADB has provided loan assistance to Pakistan (the ADB assistance has been provided for elementary and secondary school girls, secondary school science, elementary education, teacher education, technical education, and social sector service delivery under the newly devolved administrative system of approximately 100 districts nationwide) for educational development and will continue to support federal, provincial, and especially district efforts to reform education [12].

In its study, $\mathrm{ADB}$ [12] reported that Bangladesh is a nation of 125 million with a gross enrolment rate of about 95 per cent but high dropout in elementary schools. Given the historical ties to modest public spending, it has been a struggle to provide universal education especially in remote areas. Consequently, ADB has emphasised basic education as a means to enroll more students, especially girls, in elementary education. Many NGOs and private institutes have entered into the provision of primary education in rural areas. These efforts have helped to remove pressure on the public education system that still lacks capacity to provide universal basic education. $\mathrm{ADB}$ has taken a lead role in mobilising donors to assist Bangladesh's basic education 
sector through wide programming. $\mathrm{ADB}$ also supports nonformal, secondary, and teacher education in Bangladesh.

ADB further pointed out that India is a nation of over 1.2 billion inhabitants and has a gross enrolment rate of about 90 per cent. Given the large number of rural inhabitants, it is difficult to keep large numbers of students in school where the relative opportunity cost to rural labour is high. $\mathrm{ADB}$ does not provide assistance in education to India, partly because India does not qualify for soft loans from ADB and partly because the government believes that it can meet the needs of its children without external aid. This decision to fund basic education, mostly from local resources, has farranging implications, and only time will tell if the decision was appropriate [12].

Yet, in another study, ADB revealed that Sri Lanka is a nation of about 20 million inhabitants. The gross enrolment rate has been over 100 per cent for many years, so attaining universal basic education is not as pressing as in other South Asian nations. ADB supports secondary and postsecondary education in Sri Lanka, usually through skills development and human resource endowment funds. Also, ADB has assisted Sri Lanka to implement distance learning in the Open University as well as to provide computers in secondary schools to improve teaching and learning [12].

It is in the light of these problems that this paper examines various educational reforms that have been undertaken in PNG in both colonial and postcolonial period and their role in national educational development.

1.2. Method of the Study. The study involved a total of 40 participants consisting of teaching staff from four primary schools in Boma Yang area of Lae city in PNG. The primary schools from which data was collected were (1) Lana Kapi Primary School, (2) Taraka Primary School, (3) Lae Adventist Primary School, and (4) Lutheran Primary School. From each school, ten teachers were interviewed with open ended questionnaires. All the selected Primary Schools have the enrolled students ranging from 350-600. The percentage of girl students is found to be less than 40 . The data was also gathered through a variety of methods including in depth interviews, participant observation, focus groups, and documentary analysis.

The participants in the study were 40 teachers in 4 primary schools of PNG during the third term of academic session 2008. The data was collected from 6 to 24 October, 2008. Among the teachers interviewed, there were 15 graduates and 25 teacher training diploma holders made up of twenty seven (27) males and thirteen (13) females. While their chronological ages ranged between 21 and 50 years, their years of teaching experience ranged from 2 to 21. These classes of teachers were chosen because of their exposure to theories and models of selection during their preservice courses of studies in the colleges of education or universities. Besides, the research data also collected from secondary sources such as reports of the Ministry of Education, Australian Aid, and the Asian Development Bank. Some of the results were not presented in the paper due to the inconsistencies and gaps. In other words, the results and perspectives of the respondents were partly presented in the paper due to circumstances beyond researcher control.

The paper has been divided into five sections: Section 2 deals with the educational background of PNG, Section 3 provides educational quality and curriculum, Section 4 presents' results and discussion of the study, and Section 5 presents the concluding remarks of the study.

\section{Educational Background}

2.1. Profile of PNG. Papua New Guinea occupies 462,840 square kilometers of land and water off the coast of Southeast Asia. PNG is the second largest island in the world and comprises about six hundred smaller islands between the Coral Sea and the South Pacific Ocean. Papua New Guinea's 6 million people (July 2008 estimate) speak more than 715 different languages. The government recognizes English as the nation's official language, but only 1-2 per cent of the population speaks it. Pidgin (a mixture of English), German, and other languages, is spoken throughout the country.

Papua New Guinea remained fairly isolated from Western influences until the nineteenth century although infrequent contacts were documented as early as the 1500s. The Dutch annexed the western half of New Guinea between 1828 and 1848. The British and Germans divided the eastern half in 1885; Great Britain took the south, and Germany took the north. Great Britain transferred control of the southeastern portion of New Guinea to Australia in 1902, which renamed it Papua [13]. Australia seized the northern region during World War I and assumed complete control of eastern New Guinea under a League of Nations mandate. The Japanese occupied most of the colonized areas of New Guinea during World War II [14]. However, after the war, control of the island reverted to Australia as a United Nations trusteeship. Australia maintained control until Papua New Guinea claimed its independence in 1975 (Indeed, PNG has moved from the Stone Age into the 21st century in the blink of an eye in world historical time-less than a hundred years. Some communities are so remote that even today, that it is a rarity for them to have any contact with people other than those from their own immediate clan area.).

Since independence, Papua New Guinea has functioned as a parliamentary democracy, with a capital in Port Moresby and 19 other administrative provinces. About 15 percent of the population lives in major urban areas and the rest live in rural areas. The country's national currency is the Kina (K1.00 equals about US\$ 0.36 as of 28 January 2009). According to the Human Development Report 2006, PNG's Human Development Index (HDI) is found to be 0.523 and GDP per capita \$2, 543 [2].

2.2. Historical Background. Historical development of PNG education system and its vision in fostering national development has been discussed in this section. Before the European colonization, the adults in each tribal society in Papua New Guinea educated their children on practical skills, social behaviour, and spiritual beliefs. In 1873, the London Missionary Society established the first school to teach islanders 
to read scripture. After 1884, German and English missionaries established primary schools to teach Western concepts of morality, the German and English languages, arithmetic, and the Christian doctrine. During the early 1900s, the British government encouraged missionaries to develop vocational education programs in Papua New Guinea to produce better farmers, crafts people, and skilled labourers [3]. As stated earlier, in 1914, Australia took control of the German colony in north-eastern New Guinea. With Papua and New Guinea under its reign, Australia established English as the official language of instruction and laid the foundation for modern education in Papua New Guinea.

At independence, PNG found itself with a need for high percentage of skilled manpower to run its economy. In order to solve this, there is a need to set up a Commission that can survey existing educational resources and to advise the government on the formation and implementation of the required national policies for education. The organization of education is closely linked to the management of human resources and the labour market. This link led to the growth of enrollments, especially in primary and secondary schools, a growth that continued to be experienced in the 1990s [15]. Although formal education was expanding during this period, it was not directly accompanied by economic growth. Thus, most of the school dropouts were soon left out with neither jobs nor training. By 2007, the majority of secondary school dropouts began to experience unemployment crisis. Due to an increased demand for higher education and the need for highly qualified manpower, the government made more acts in the 2000s that were geared towards the improvement of education to enable it foster economic and social development. There are three more universities established both by government and by private (or by missionaries). A critical examination of various educational acts that were undertaken during this period illustrates the government's commitment to the improvement of education and the emphasis is placed on its ability to develop the nation.

In PNG, education is structured: Elementary School (Prep., Grade 1, and Grade 2), Primary School (Grade 3 to 8), Lower Secondary School (Grade 9 and Grade 10), and Upper Secondary School (Grade 11 and 12). The primary schools, or community schools, provide six years of instruction for children 7-12 although attendance is not compulsory. Most instruction still occurs in English. However, in 1989, the National Department of Education (NDoE) adopted a language and literacy policy. The 1989 Language and Literacy Policy also supported local language and cultural instruction at secondary and tertiary schools and local language literacy programs for adults [3].

In order to address issue of local language, there is a need to have the use of the vernacular language and Tok Pisin during the transition from elementary to primary school in PNG. Besides, there are significant issues with this language reform and providing instruction in the vernacular mainly due to the lack of qualified teachers from rural areas who are available and willing to teach in schools. In many cases, teachers from outside communities, who do not speak the vernacular, are posted to the elementary and primary schools and have no choice but to instruct students in Tok Pisinusing broken English to transition students to full instruction in the English language. It is observed that there are problems with this approach. Another important problem that was noticed in schools was resource distribution and the many problems with actually delivering the textbooks and other learning materials to remote and isolated rural areas of PNG.

Additionally, students who reach sixth grade must pass a national exam to continue their education further. PNG maintains two types of secondary schools: the four-year provincial high schools, Lower Secondary School (Grade 9 and Grade 10), and Upper Secondary School (Grade 11 and 12). Large towns generally have their own secondary schools, but students from rural areas often attend provincial boarding schools. English is the language of instruction at the secondary level. Students who do not attend secondary school can enter two-year vocational schools or continue their education by the government-operated College of Distance Education [15].

Of those who continue to seventh grade, about 67 per cent complete the tenth grade. In the tenth grade, students must pass a second national exam to receive a lower Secondary School Leaving Certificate. Most of them end their education after tenth grade, but about 20 per cent enter one of the four national high schools. The retention rate for the national high schools is about 95 per cent [16]. Students, who complete twelfth grade, face a third national exam that determines higher educational opportunities for the students at college/university level. Regardless, most grade twelve graduates pursue some form of higher education. Students also can enter a two-year vocational or technical school after tenth grade. Those who complete the upper secondary level earn a Sixth Form Certificate or a High School Certificate, depending on the school they attend. A few of the best tenth graders enter a one-year university preparation program at the University of Papua New Guinea, but most of these students gain university acceptance by passing the National High School Examination at the end of twelfth grade.

In the 1990s, the government changed its policy on education. This was because of difficulties faced by the graduates of that education system, especially at the primary and secondary levels. Most of the graduates who were matriculating from these levels could not be absorbed into the shrinking labour market. Besides, there was a low enrolment and high dropout rates, significant gender and regional disparities, and a curriculum lacking relevance to most of PNG's children. This made the government to reconsider changing its education system.

In line with this, the government of PNG has introduced educational reforms in 1993 (the introduction of the education reforms in 1993 resulted in the structural reform of nine years of basic education that included elementary prep., one and two, and primary grades three to eight while making grades nine to 12 the levels in secondary school). The aim of the reform was to achieve sustainable, quality, universal basic education, and a more productive, skilled population. The National Educational Plan outlines the intended outcomes for education in PNG and the strategies for achieving them [17]. The educational reform advocated for a more practical 
curriculum that would offer a wide range of employment opportunities, ensuring equitable distribution of educational resources throughout the country. Education system was expected to ensure that students graduating at every level had some scientific and practical knowledge that could be utilized for self-employment, salaried employment, and further training [18]. It placed a greater emphasis on practical and technical aspects of education. Education under this reform policy was designed to provide lifelong skills and make individuals self-sufficient and productive in agriculture, industries, and commerce.

The central aim of the educational reform was to provide within ten years a full primary course for undergraduate teachers to ensure that there was adequate supply of trained teachers. In addition, a satisfactory number of pupils of both sexes were expected to receive education up to the certificate level. The plan, however, was not implemented for the whole cost of primary education was to be borne by provincial and local government authorities that had inadequate finances.

2.3. Australian Aid for Educational Development. The major objectives of the Australian education assistance are to work in partnership with the PNG government and other donors to implement the PNG educational reform agenda and to refine and implement its National Education Plan (NEP) for the period 2005-2015. In line with this, the government of Papua New Guinea and government of Australia have agreed to pursue significant measurable progress towards the achievement of Universal Basic Education by 2015.

The partnership will support and strengthen Papua New Guinea's Education Sector Improvement Program, which is implementing the Universal Basic Education Plan, towards the targets of:

(i) increasing net enrolment rate at primary and elementary level,

(ii) maximum class size at elementary and primary schools of 45 ,

(iii) improved performance by students completing grade eight,

(iv) the percentage of primary and elementary school pupils who are female increases towards the target of gender equality,

(v) improved management capacity at all levels of the education system [19].

According to the Aus Aid, 2010 report, the school enrolments are on the increase, Papua New Guinea is struggling to educate an estimated 2 million elementary- and primary-aged children. The report identified the following key challenges.

\subsubsection{Key Challenges}

(i) Over 500,000 children aged 6-12 do not go to school.

(ii) It is estimated that half the adult population cannot read or write.

(iii) More boys than girls go to school and complete basic education. (iv) More classrooms are needed.

(v) Teachers need more training.

(vi) Management and financing from a national to school level needs strengthening.

Prime Ministers Michael Somare and Kevin Rudd have committed to increasing PNG's basic education net enrolment rate from 53 per cent in 2007, to 70 per cent in 2015, which amounts to an additional 300,000 children in school.

\subsubsection{Key Areas of Australian Support}

(i) subsidies to schools, to remove school fees for the first three grades of elementary,

(ii) classrooms, teacher houses, and other school buildings to improve access to schools,

(iii) materials including textbooks to improve the quality of education,

(iv) teacher education to improve the quality of teaching.

2.3.3. Results. In recent years, significant progress has been made in the enrolment and retention of primary and elementary students.

The net basic education enrolment rate has increased from 52 per cent in 2007 to 63 per cent in 2009.

School completion rate has increased from 45 per cent of enrolled students completing grade 8 in 2007 to 56 per cent in 2009 .

\subsubsection{Specific Achievements Made through Australian Assist- ance in 2009 Include the Following:}

(i) construction of 176 double classrooms, 47 teacher houses, and 13 other buildings such as library, administration, toilets, and fencing in 229 schools,

(ii) maintenance grants to 189 schools for small rehabilitation works,

(iii) procurement of 539000 primary school textbooks delivered in the first half of 2010,

(iv) printing and distribution of 180,000 HIV/AIDS booklets to schools and provinces,

(v) in-service teacher training to 33,000 teachers including the production of training manuals,

(vi) 61 per cent of schools have adopted the School Learning Improvement Plan model to improve school management,

(vii) training of Board of Management teams including monitoring and supervision to 2284 primary and 225 elementary schools,

(viii) better information management systems including Department of Education website [19]. 
2.3.5. Textbook Distribution. Increasing the enrolment rate of children in primary school is about more than just increasing student numbers. Teachers need to be trained, curricula designed, and classrooms and resources sourced and maintained.

At the start of 2010, twenty shipping containers holding 539,000 primary school textbooks arrived in Port Moresby and Lae to be distributed to schools nationally. Books which focus on core subjects of maths, science, and language for grades 6, 7, and 8 , were selected by PNG Department of Education primary curriculum officers and funded by the Australian government. Each primary and community school in the country and eight teacher training colleges received a set of 159 books with AusAID supporting the National Department of Education to distribute books to schools across PNG. The texts are especially important for the remote schools, where it is difficult to place resources [19].

Further, Australia has aligned its educational support program more closely with PNG government systems to increase the sustainability of its educational assistance. Australia anticipates that this would entail Papua New Guinea, Australia, and other donors to deal in a more synchronized and concerted direct way with the systemic weaknesses confronting the education sector.

Over the period of the reform Australia provided resources to increase participation and improve the quality of the education system. The aid program also aimed to build the capacity of the government of PNG to manage the education system. Over the next four years, PNG expected to receive a significant educational assistance from its former colonial master [17]. Besides, Australia will continue to provide practical support for service delivery and education outcomes for schools as well as systems improvement.

Aus Aid provides assistance in critical areas such as curriculum development and implementation, improved teacher training, textbook distribution, and infrastructure maintenance. Assistance is also provided for the development of planning, budgeting, and implementation skills of decision makers at national, provincial, and school levels. However major systemic weaknesses remain. While overall primary school enrolment rates were increased over recent years, surprisingly, many children still either do not enter school or dropped out before the end of the basic education cycle of 9 years. Maintaining minimum quality standards are proving a threat, where the regional and gender disparities remain throughout the country. The capacity of the National Department of Education, provincial education administrations, and central agencies of the PNG government to budget and manage funds effectively remains relatively weak. Subsequently, Australia's aid program has been supporting PNG's major educational activities during 2002-2008. The activities are: Education Capacity Building Program (ECBP) - \$44 million, Basic Education Development Project (BEDP)— $\$ 35$ million, and Papua New Guinea Targeted Training Facility (PATTAF)—\$20 million [17].

At present, there were more than 1 million students and over 32,000 teachers in more than 6,100 institutions in the national education system of Papua New Guinea. There had been tremendous progress in increasing access to education since the educational reforms began in 1993. In 1992, the total enrolment in primary and secondary schools was only about 500,000 students. This is two to three times faster than the population growth since the reforms started. But the number of teachers trained during this period is utterly inadequate. Further, 75 per cent of primary school-aged children attend school, but only 12 per cent of secondary school-aged children were enrolled [16, 20]. Enrolment ratios vary widely between provinces and regions. In large cities and towns, virtually all children attend school, but, in some remote highland areas, fewer than 7 per cent of children receive any formal education.

Like many developing countries in the world, gender disparity is a serious problem in PNG education. Pani [21] concluded that most parents living in rural villages and urban settlements depend on subsistence agriculture for their livelihood. The incomes they accrue from these activities are insufficient to afford vital services, including education for their children. Research shows that many parents think that the best returns are through educating sons rather than daughters. These views affect the level of support provided for their children's access, participation, retention, and completion of education at the different levels. Tables 1 and 2 presents the enrolment and number of schools and teachers in the country at different levels.

Tuition ranges from $\mathrm{K} 1,000$ to $\mathrm{K}$ 20,000 per year in both the government and private schools (although in 2010, elementary school is free, in primary school, fees are normally in the hundreds of Kina, and in secondary school, fees are in the thousands of Kina depending on the type of institution), which is unaffordable to the parents and caregivers in the country. As stated earlier, most of them are rural dwellers who depend upon subsistence farming. The amount depends on the training of the teachers at each school and the general quality of resources. It is noted that between 75 and 80 per cent of students are Papua New Guinean citizens although percentages range from 50 to 100 percent within individual schools. The remaining students come primarily from Australia, New Zealand, and the Philippines.

Many children, especially in poor, rural areas, never enroll, because their families cannot afford the school fees, which can equal more than 50 per cent of some families' earnings. Some primary and most provincial high schools charge fees, while the national high schools and most postsecondary institutions are free or subsidized with government scholarships. As part of the reform in 1993, the national government abolished some of the school fees traditionally paid by parents.

Churches also play a significant role in Papua New Guinea's educational system. In 1995, churches operated 20 training schools for nurses and other community health workers. The Catholic Church was the leading provider of educational services, running one-quarter of the community schools and one-sixth of the provincial high schools. The Evangelical Alliance, the United Church, the Lutheran Church, the Seventh-Day Adventists, and the Anglicans also provide educational services. The National Department of 
TABLE 1: Educational finance paradigm.

\begin{tabular}{lll}
\hline Level and efficiency of schooling & Internal efficiency & External efficiency \\
\hline \multirow{2}{*}{ Basic education } & High pass rates & Good citizenship \\
& Dropout prevention & Literacy/numeracy \\
\hline \multirow{3}{*}{ Secondary-education and above } & Cost-effective approaches to service & Market-based skills \\
& delivery of general education & Wage employment \\
& & On-job training \\
\hline
\end{tabular}

TABLE 2: Enrolment, number of schools, and teachers, 2001.

\begin{tabular}{|c|c|}
\hline Type of institution & 2001 \\
\hline \multicolumn{2}{|l|}{ (a) Elementary } \\
\hline Number of schools & 1,416 \\
\hline Enrolment & 98,848 \\
\hline Male & 52,089 \\
\hline Female & 46,759 \\
\hline Number of teachers & 3,449 \\
\hline Male & 2,094 \\
\hline Female & 1,355 \\
\hline \multicolumn{2}{|l|}{ (b) Primary } \\
\hline Number of schools & 1,639 \\
\hline Enrolment & 296,281 \\
\hline Male & 164,317 \\
\hline Female & 131,964 \\
\hline Number of teachers & 7,858 \\
\hline Male & 4,725 \\
\hline Female & 3,133 \\
\hline \multicolumn{2}{|l|}{ (c) Secondary } \\
\hline Number of schools & 161 \\
\hline Enrolment & 77,451 \\
\hline Male & 46,294 \\
\hline Female & 31,157 \\
\hline Number of teachers & 2,187 \\
\hline Male & 1,492 \\
\hline Female & 695 \\
\hline \multicolumn{2}{|l|}{ (d) Vocational } \\
\hline Number of schools & 138 \\
\hline Enrolment & 14,333 \\
\hline Male & 10,423 \\
\hline Female & 3,910 \\
\hline Number of teachers & 908 \\
\hline Male & 659 \\
\hline Female & 249 \\
\hline
\end{tabular}

Note: elementary to secondary numbers shown here represents government owned institutions. Statistics for vocational is both governmental and nongovernmental.

Source: National Department of Education (2003).

Education estimates that the government provides about 68 per cent of lower secondary education services, churches provide 29 per cent, and the international schools provide about 3 percent.

Australia remains one of Papua New Guinea's primary trading partners. As a developing country, PNG has continued depend on external assistance (particularly Australia) for its development programmes. Extensive foreign aid has been expended primarily to enhance the quality of education. For the development of education (like primary, secondary, distance education technologies, and youth employment skills), PNG also borrow money from ADB.

\section{Educational Quality-Curriculum and Text Books}

It is a universal fact that the quality of education is primarily depending upon the curricula, text books, and infrastructure in any country. In order to maintain a national perspective on assessment and quality control in PNG the NDoE has a national curriculum policy on all areas of study from elementary to secondary education. This is one of the first indications of ensuring that all institutions that are established in PNG under the auspices of NDOE teach the same curriculum. Presently, there is encouragement at all levels for teachers to realize the curriculum in ways that acknowledge and make connections with the local context. This is a point that is currently being emphasized in elementary education where teaching is being done using local vernacular and the development of experience and knowledge based as much as possible within the local context. As the cycle of education moves from elementary to primary, a national curriculum is developed through various areas of specialty (subjects) to be studied in schools [22].

The overall procedure for choosing instructional materials for classroom instruction in PNG is most often the joint responsibility of curriculum developers, NDoE officials, and other stakeholders. Based on its function and medium of delivery, instructional materials may have, prior to classroom use, been subjected to a selection process by the appropriate body such as the NDoE, media, or resources centre. The final decision as to what strategies and materials are to be used in the classroom for a particular instruction is, however, the prerogative of the teacher who is influenced by such other factors as their professional background, nature of learning task, learners' study habits, availability and accessibility of materials, among others.

In order to achieve the quality education in PNG, the learner, teacher, content and materials, the learning styles, or study habits of the learners must be considered in the choice of instructional strategies and materials. Instructional strategies are said to be plans for teachers to follow in order to realize the stated teaching-learning objectives. A viable teaching strategy, thus, works towards the realization of the 
quality educational objective(s). It equally determines to a large extent the type and form of instructional media to be adopted in an instructional situation.

The teaching-learning process involves a purposeful interaction between the teacher and the learner through effective selection and use of appropriate content, strategies, and materials. An effective teacher has been described as one who not only selects and uses a variety of instructional strategies and materials but who also has the appropriate materials [23].

Table 3 presents the assessment of sources of influence on teacher's choice and use of materials. Analysis of instructional strategies frequently adopted by teachers shows that behavioural strategy of teacher which attracts 50 per cent of teachers and availability and accessibility of materials attracted by 45 per cent of the teachers. Table further reveals that majority of the teachers are in a better position to use different methods and strategies that may attract more students to attend the classes. However, there was less number of teachers who never used any materials that can make the classroom atmosphere more effective and interesting to the students.

The National Department of Education has provided textbooks to students since the 1990s. Prior to this, the teachers relied on syllabi and teaching guides from the Department of Education's curriculum unit, which outlines what teachers should teach and how they should teach. The production of education materials improved through the two loans from the World Bank; the loans indeed helped pay for primary textbooks in English, math, health, and community life and for secondary textbooks in English, math, science, and social studies. Most of the textbooks still are published in English; however, the NDoE has explored producing resource materials that can be translated and adapted to the local languages [16]. In addition, the curriculum unit provides curriculum statements, teachers' guides, in-service packages, radio broadcasts, videos, posters, science kits, practical skills and home economics kits, sports equipment, agricultural tools, and expressive arts equipment. As of the early 1990s, computers were not available to schools, but currently, ICT education has become part of learning in most of the high schools but not the primary schools.

Prior to 1990s, primary schools have received free textbooks at a rate of one textbook for every two students. However, many teachers do not incorporate them into their teaching styles or cannot access them because of distribution problems. The community schools also lack sufficient reading materials. Our survey results reveal that out of the four schools surveyed all of them do not have adequate text books.

\section{Results and Discussion}

In the postcolonial period, PNG's struggle for political independence has not served much for its educational development, as PNG still depends on Australia for economic aid/support. During the struggle for independence, the nationalists aim, in terms of education, was to produce an education philosophy that would serve immediate needs of the country.

The expansion of Papua New Guinea's education system would not continue until the country begins to produce a greater number of qualified teachers. As evidenced from the government report, PNG is still working to improve student retention rates, especially in the community schools, and to increase the transition rates into the secondary schools [16]. Providing instruction and literacy materials in the local languages will help the country achieve these goals.

In general, the schools in PNG are facing many problems, and this is particularly observed in the four schools during our survey: overcrowding, limited or obsolete libraries, insufficient equipment, outdated curriculum, and underqualified teaching staff, to name just a few. Unless and until the quality is improved in schools, the quality of education at tertiary level can be affected and thus graduating students every year from weak programs, and they will be ill-equipped to satisfy the development needs of the country or to compete internationally.

Due to large populations of PNG young unemployed adults and out-of-school youth, including those who migrate from rural to urban areas, there is immense need for skills development programmes that lead to wage employment at all levels and that can be linked to technical education and to human resource development funds.

Analysis of the demographic survey data showed that the respondents' chronological ages ranged from 21 to 50 years and their teaching experiences were between 2 and 21 years. The type of instructional materials available, accessible, and frequency of their use showed that the most available and accessible materials included maps and globes, poster, textbooks and other objects like drawing and paintings, bulletin broads, wall charts, and still pictures are widely used by the teachers. Of these, the most frequently used included textbooks real objects and posters. Although most of the school teachers and students have a good command over English, it has been observed that the students are found to be weak in other subjects' particularly in mathematics and in sciences.

Amidst these struggles one question emerges: what is the possible good that is expected to come out of PNG education? Put differently, what is the function, if not the meaning, of education in PNG today? No society anywhere in the world educates its people without having good reasons for doing so. Obviously, no society or government will spend so much time, energy, and money on education, if it does not serve any purpose at all. Despite enormous investment in education over the years, the PNG education system has generated a number of severe predicaments. The initial postcolonial euphoric confidence in education has to a considerable extent been replaced by a mood of disillusionment. The education system has been accused of being egocentric and materialistic at the expense of collective effort and responsibility, of adopting irrelevant and rigid curricula, of embracing antiquated teaching and learning techniques, of dampening initiative and curiosity, of producing docile and dependent-minded graduates, and of widening the gap between the rich and the poor. 
TABLE 3: Assessment of sources of influence on teacher's choice and use of materials.

\begin{tabular}{|c|c|c|c|c|c|c|}
\hline \multirow{2}{*}{\multicolumn{2}{|c|}{$\begin{array}{l}\text { Source of influence } \\
\text { S. no. }\end{array}$}} & \multicolumn{5}{|c|}{ Frequency of choice and use } \\
\hline & & Frequently & Occasionally & Seldom & Never & Total and $\%$ \\
\hline 1 & Behavioural objectives of lesson & $20(50.0)$ & $10(25.0)$ & $8(20.0)$ & $2(5.0)$ & $40(100.0)$ \\
\hline 2 & Availability and accessibility of materials & $18(45.0)$ & $14(35.0)$ & $5(12.5)$ & $3(7.5)$ & $40(100.0)$ \\
\hline 3 & General goals of curriculum & $13(32.5)$ & $16(40.0)$ & $6(15.0)$ & $5(12.5)$ & $40(100.0)$ \\
\hline 4 & Professional training of Teachers & $12(30.0)$ & $13(32.5)$ & $8(20.0)$ & $2(5.0)$ & $40(100.0)$ \\
\hline 5 & Teachers' intuitive efforts & $13(32.5)$ & $14(35.0)$ & $6(15.0)$ & $7(17.5)$ & $40(100.0)$ \\
\hline 6 & Contents of lessons & $10(25.0)$ & $19(47.5)$ & $6(15.0)$ & $5(12.5)$ & $40(100.0)$ \\
\hline 7 & Learning styles of pupils & $11(27.5)$ & $17(42.5)$ & $4(10.0)$ & $8(20.0)$ & $40(100.0)$ \\
\hline 8 & Analysis of Learning task & $15(37.5)$ & $12(30.0)$ & $7(17.5)$ & $6(15.0)$ & $40(100.0)$ \\
\hline 9 & Information from E.R.C.S. & $14(35.0)$ & $18(45.0)$ & $5(12.5)$ & $3(7.5)$ & $40(100.0)$ \\
\hline 10 & Attributes of Materials & $16(40.0)$ & $13(32.5)$ & $6(15.0)$ & $5(12.5)$ & $40(100.0)$ \\
\hline
\end{tabular}

Source: survey data.

Note: figures in parentheses are the percentages in relation to total.

4.1. Implications. The study concluded that the quality of leadership demonstrated to lead the educational change has been disappointing. Inadequate leadership at the administration and curriculum levels had a negative impact on the quality of education [6]. Achieving quality education has also been hampered by inadequate funding, scarcity of skilled human resources, and inappropriate infrastructure in all educational institutions [24]. Recently introduced twoyear trimester programme has improved access and quantity but at the expense of quality. To assist the primary education and thus implement the reform agenda, enormous amount of foreign aid is required. The government of PNG has embarked the Primary and Secondary Teacher Education Project (PASTEP) [25]. Although, the PASTEP made substantial contributions, the project not free from criticism; therefore, it is recommended that in accepting foreign projects, PNG needs to establish strategies to ensure equitable partnerships with all stakeholders for sustainable development in education.

There is a need to examine the scope, content, methods, administration, and financing of primary education in PNG. The government of PNG must emphasise on the provision of practical education to its citizens to improve the quality. It is important to note that there is a high level of wastage that is evident in PNG education sector.

Despite the budgetary increase for education, providing access to education and training of teachers is still one of the greatest challenges in the reform process. Like other AsiaPacific nations, the need to expand education opportunities is not fast enough to keep up with overall population growth or to get education to many people who have never had it. It is now unsure how many children in Papua New Guinea still cannot go to school. It is also a fact that across the nation, the level of literacy in adults is low compared to the Pacific neighbours [12].

For all these reforms to be implemented successfully, there should be more and more trained teachers in schools. The existing Teacher Training Colleges cannot cope up with the demand. Training of teachers in the distance education mode is the only viable solution considering the huge amount of money involved in training teachers in the normal mode [26]. The perspective plan should be prepared for speeding up of output of high-level PNG workforce by expanding secondary and higher education. By 2020, the pace of PNG education should be changed, and there must be improvement of both quality and quantity for the required training of more manpower that could manage various sectors of the PNG government. Most of the citizens in PNG are still lacking adequate access to education [17].

Papua New Guinea will face several education dilemmas as long as most of its population remains tied to the agricultural economy. Education officials must find ways to provide a relevant education to the 85 per cent of students who remain in their rural and semirural communities and prepare the remaining 15 per cent who find paid employment in government, business, and service industries (PNGDOFT) [25]. In general, the education most children receive does not lead to formal employment; at the same time, it alienates them from the skills they need to contribute in their home communities. But, if the government can maintain its financial commitment to education, then Papua New Guinea's educational system most likely will continue to progress.

To improve the quality of education in PNG, students and other stakeholders should have the following.

(a) A willingness to contact the teachers/instructors for assistance when necessary, as more frequent contacts with the teachers/instructor will motivate them further,

(b) a more serious attitude towards the curricula and continuous upgradation,

(c) timely feedback regarding course assignments, tests, examinations, and projects (if any) should be given,

(d) learners will benefit significantly from their involvement in small learning groups. The group will have the feeling that if help is needed, it is readily available most of the time,

(e) there must be an emphasis on work-related learning that can impart employability skills. 
The government of PNG has to be realized that education was not doing much to achieve its stated objectives. Education was viewed as being too academic, and the performance of the PNG educational system in the utilitarian, personal, social, and cultural goals was not significant [15]. For instance, the number of school leavers begun to swell as job opportunities became scarce. Rate of unemployment grew as school leavers went to urban centers to seek for white-collar jobs. The youth were displaced at home (rural areas), where agriculture and technical jobs were in abundance, and they migrated into urban centers where they struggled for the few available jobs. This situation has created more thieves and anti-social elements which threatened the social security of the country.

Curriculum was seen as narrow and emphasized more on the passing of national examinations and acquisition of certificates. This led to the formation of Education Sector Capacity Development Programme to address these challenges [17]. The education system was required to provide high-level skills that were needed for favorable PNG economic and industrial growth. It emphasized constraints imposed on development by underutilization of human capital and the lack of appropriate skills in all government sectors $[9,24]$. This is high time that the education system in PNG required, among other things, to provide high level skills needed for economic, industrial, vocational, and technical training that is essential for employment and the promotion of attitudes favorable to national development $[18,27]$.

\section{Conclusion}

From the outset, the emphasis on educational expansion that took place during the postindependence period was complemented by an increasing priority accorded to programmes of quality improvement. The rationale behind this was to underscore the role of education in national development. In the first two decades of independence (1975-1995), curriculum reforms played a pivotal role in directing the expected quality of development in PNG. Major innovations were introduced in the curriculum, namely, the new mathematics, agricultural, industrial, and science education and the new primary approach, among others. These curriculum efforts unfortunately did not bring the desired quality in the PNG education system. They failed to respond to the problems of low-quality curriculum materials, irrelevant content, and inappropriate instructional approaches and contributed minimally to PNG developmental agenda.

Although PNG educational goals have differed in both colonial and postcolonial periods, they have been closely linked to PNG's evolutionary and reformative processes. In the first decade after independence, the government policy was more on decolonizing the education system and producing the required manpower for national development. The second decade aimed at making education beneficial to the individual and the nation. During this period, the reforms were introduced. However, there is a growing criticism among the educated community and other stakeholders regarding the educational reform. As a result, the government of PNG decided (end of 2008) to conduct an extensive audit of the national education system's school curriculum reform that it took on board in 2003 (after 10 years of educational reforms, in 2003, the primary and lower secondary curricula was revised based on local and provincial needs and thus to improve the quality of education in the country). By and large, examinations of educational reviews that have been undertaken in PNG in the postcolonial period indicate that they have operated under the framework of the country's national goals.

Our survey findings reveal that there is a glaring gap between theory and practice. A cursory glance at schooling in PNG today will show that educational practice suffers chronically from what Dore [28] identified as the "diploma disease" over three decades ago. Both the formal curriculum and its objectives are intentionally subverted in order to give way to an entirely new curriculum, an informal curriculum, overtly meant to guarantee success in examination. The sole criterion of educational quality, it appears, is high performance in national examinations. Whatever various education commissions and reports have stated about the importance of attitudes and values of practical skills, an allround development is conveniently forgotten and is rather crudely replaced by a very opportunistic theory of education.

Pedagogy of hope is expected to transform the learner into a problem-solving agent, a creator rather than a creature. To this end, educators in PNG must go beyond mere transmission of factual knowledge. Instead, educators must present knowledge, skills, and values that are liberating, in as far as they create new horizons and new opportunities that are vital for societal growth $[4,6]$. The learners too must become critically aware of their potential as humans, of their "power to use circumstances rather than being used by them" (Nyerere) [29]. Last but not least, education is a central component of any nation's developmental process, and for it to facilitate this function, the process should be clearly defined, legislatively protected, owned by relevant stakeholders, adequately financed, and constantly subjected to periodic reviews to ensure better quality that it is in harmony with societal needs.

\section{Acknowledgment}

The author would like to thank the editor and anonymous referees for their comments and insights in improving the draft copy of this paper.

\section{References}

[1] United Nations, The Millennium Development Goals Report 2005, United Nations, New York, NY, USA, 2005.

[2] United Nations Development Programme(UNDP), Human Development Report, UNDP, New York, NY, USA, 2006.

[3] National Department of Education (NDoE), Education Sector Review: Vol. 2, Deliberations and Findings, Department of Education, Waigani: Papua New Guinea, 1991.

[4] T. W. Schultz, "Investment in human capital," American Economic Review, vol. 51, no. 1, pp. 1-17, 1961. 
[5] United Nations Educational, Scientific and Cultural Organisation (UNESCO), World Education Report, UNESCO, Paris, France, 2000.

[6] R. Rena, "Financing education and development in Eritreasome implications," Manpower Journal, vol. 43, no. 1, pp. 7397, 2008.

[7] T. W. Schultz, Investing in People, University of California Press, Berkeley, Calif, USA, 1981.

[8] F. H. Harbison, Human Resources as the Wealth of Nations, Oxford University Press, New York, NY, USA, 1973.

[9] G. Psacharopolous, Education and Development: A Review, World Bank, Washington, DC, USA, 1988.

[10] J. M. Gore, The Struggle for Pedagogies, Routledge, New York, NY, USA, 1993.

[11] W. Loxley, Financing Education: Perspectives of the Asian Development Bank, Commonwealth Education Partnerships, Manila: ADB, 2004.

[12] Asian Development Bank (ADB), Education Policy and Strategy, Asian Development Bank, Manila, Philippines, 2003.

[13] A. Turner, Historical Dictionary of Papua New Guinea, The Scarecrow Press, Metuchen, NJ, USA, 1994.

[14] J. Rannells, PNG: A Fact Book on Modern Papua New Guinea, Oxford University Press, Oxford, UK, 2nd edition, 1995.

[15] National Department of Education (NDoE), Primary Education Handbook, PNG National Department of Education, Waigani: Papua New Guinea, 1999.

[16] National Department of Education (NDoE), "Elementary Curriculum: Language," Department of Education, Port Moresby, Papua New Guinea, 2003, http://www.pngcurriculumreform.ac.pg/elementary/index.htm.

[17] Aus Aid, Australian Aid Development program, 2009, http:// www.ausaid.gov.au/country/png/priority_education.cfm.

[18] J. Waiko, State of Technical and Vocational Education in Papua New Guinea. A Statement to the National Parliament, Ministry of Education, Papua New Guinea, 1996.

[19] "Aus Aid Schedule to the Papua New Guinea-Australia Partnership for Development," 2010, Priority Outcome 2: Basic Education, http://www.ausaid.gov.au/country/pdf/outcome_education_schedule.pdf.

[20] M. Morauta, "From recovery to reconstruction. The presentation of the 2001 budget to parliament," Papua New Guinea: Department of Finance and Treasury, 2000.

[21] T. Pani, "The benefits of investing in female education and the significant social role they play," (National Research Institute of Papua New Guinea, the Educational Studies Division Report Port Moresby, NRI Publication, 2006.

[22] M. A. Mel, "Quality assurance and assessment in education in Papua New Guinea," Educational Research for Policy and Practice, vol. 6, no. 3, pp. 219-228, 2007.

[23] G. S. Ibe-Bassey, "Selecting instructional materials within the process of planning lessons," Journal of Research in Curriculum, vol. 5, no. 1, pp. 45-56, 1987.

[24] R. Rena, "Factors affecting the enrollment and the retention of students at primary education in Andhra Pradesh-a village level study," MPRA Paper 22, Essays in Education, South Carolina, Calif, USA, 2007.

[25] Papua New Guinea Department of Finance and Treasury (PNGDOFT), “The 2008 Budget," Department of Finance and Treasury, Port Moresby, Papua New Guinea, 2008, http:// budget2008.treasury.gov.pg/.

[26] R. Rena, "Distance education in Eritrea: recent developments and future prospects," International Journal of Education Economics and Development, vol. 1, no. 4, pp. 320-337, 2010.
[27] M. Bray, "Papua New Guinea," in Education's Role in National Development Plans: Ten Country Cases, R. M. Thomas, Ed., pp. 197-214, Praeger Publishers, New York, NY, USA, 1992.

[28] R. Dore, The Diploma Disease, Allen and Unwin Books, London, UK, 1976.

[29] J. Nyerere, "Adult education and development," in The Tanzanian Experience, H. Hinzen, Ed., UNESCO, Hamburg, Germany, 1979. 


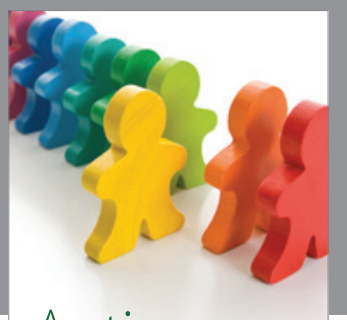

Autism

Research and Treatment
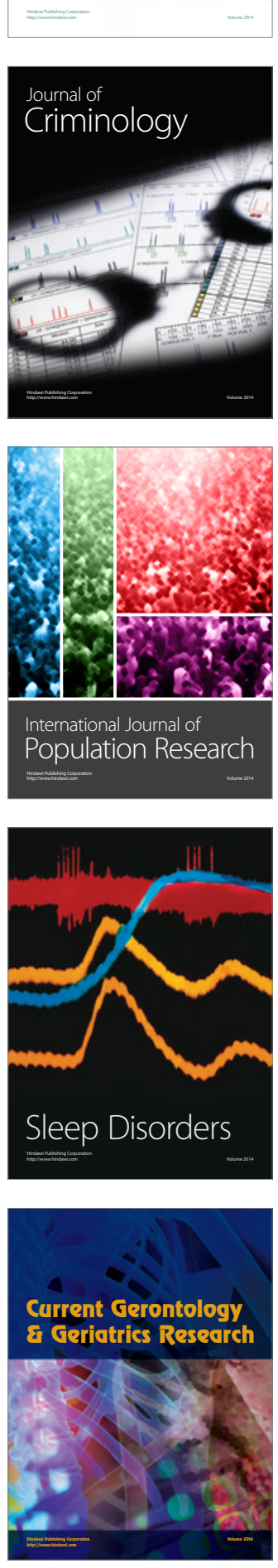
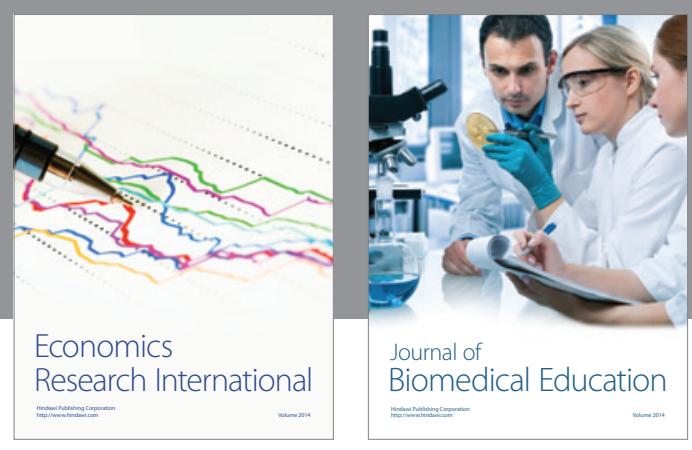

Journal of

Biomedical Education

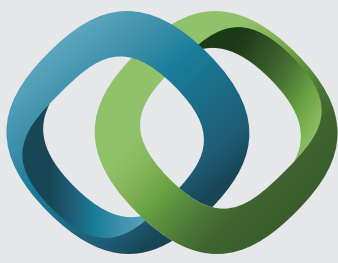

\section{Hindawi}

Submit your manuscripts at

http://www.hindawi.com
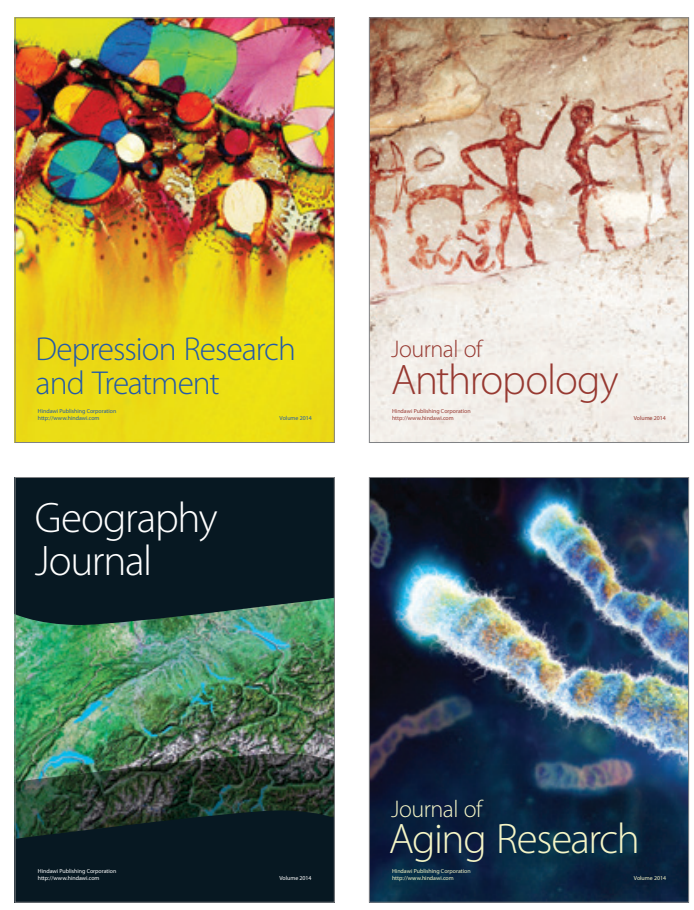

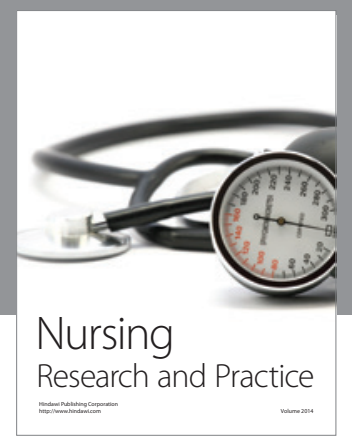

Nursing

Research and Practice

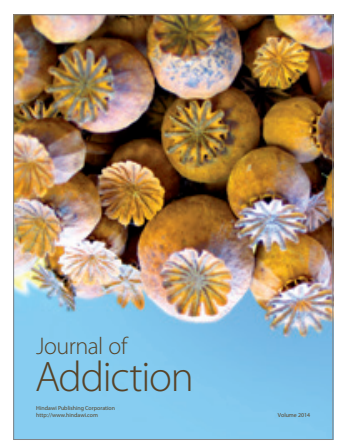

Child Development

Research

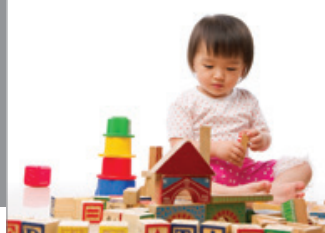

迥
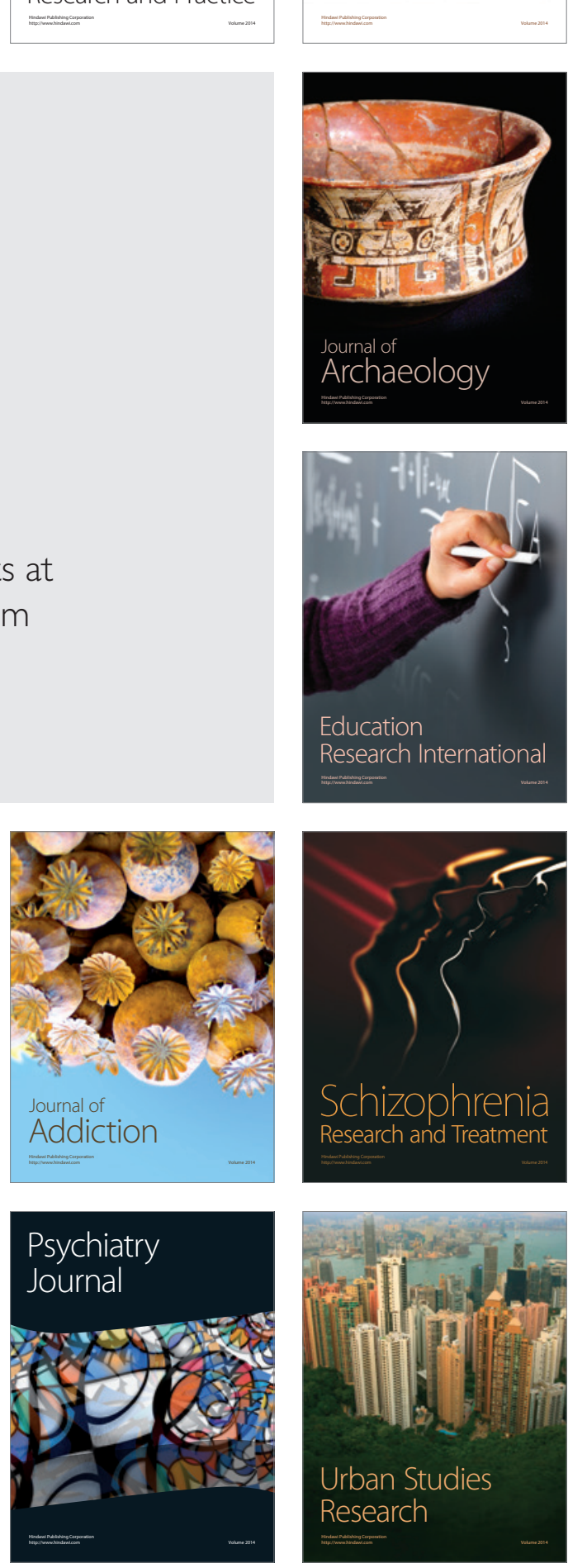